\title{
15 \\ Conclusion: What is the future of strategic studies?
}

\section{Paul Dibb}

Strategic studies in Australia seems to be undergoing a period of introspection about what to focus on, with concerns about whether it is still relevant to a greatly expanded agenda of 'national security challenges'. There is the further issue of whether strategic studies should be separate from the study of international relations. Then there is the long-standing debate about whether the label 'strategic and defence studies' is a proper area for academic study, given its concern with military matters. All these issues have been touched upon-to a greater or lesser extentin these chapters, themselves based on the Strategic \& Defence Studies Centre's 50th anniversary conference in July 2016.

The purpose of this conclusion is to discuss the foregoing issues, analyse the pros and cons of particular areas of enquiry by strategic studies, and identify future priorities for research from an Australian perspective. My aim is to open up an important area of scholarly discussion about the direction of strategic studies in the second decade of the 21 st century. Let me begin, however, by reflecting on some of the earlier challenges facing strategic studies as an academic discipline and the lessons we can learn. 


\section{Strategic studies and its critics}

Concern about the appropriateness of strategic studies as an academic discipline is not new. In 1968, Hedley Bull wrote an article in the journal World Politics called 'Strategic studies and its critics', and, in 1981, Robert O'Neill wrote an SDSC paper called Strategic Studies and Political Scientists: Strategic Studies and Its Critics Revisited. ${ }^{1}$ These two papers aimed to answer the critics of strategic studies in two very different eras. Hedley Bull was writing in the midst of the Cold War about moral questions surrounding the issue of nuclear war, whereas Bob O'Neill wrote at a time when the Vietnam War-which ended in 1975-was still fresh in the minds of Australians as a highly contentious military intervention with our US ally.

Let me turn to Hedley Bull's line of reasoning and its relevance to the current debate. First, I shall address what he meant by the term 'strategic studies'. He begins by proposing that strategy in its most general sense is the art or science of shaping means so as to promote ends in any field of conflict. But he goes on to argue that in the narrow sense in which he is using it, the sense in which 'strategy' is interchangeable with 'military strategy', it is 'the art or science of exploiting military force so as to attain given objects of policy'. ${ }^{2}$ Elsewhere, he argues that 'the military balance is itself the most important source of security'. ${ }^{3}$ It should be noted that he was arguing this in the context of the central nuclear balance between the United States and the Soviet Union. My own view is that strategic studies essentially deals with the role of force in international society. However, that definition is to be interpreted broadly: it should study how military forces are used both directly and indirectly, including for coercion, deterrence and what Coral Bell would have called signalling. This use of force may be present or potential, direct or indirect, short or long term. ${ }^{4}$ I recognise that strategic studies in the current era must go well beyond such a rather

1 Hedley Bull, 'Strategic studies and its critics', World Politics, July 1968, pp. 593-605; reprinted in Hedley Bull on Arms Control, ed. Robert O'Neill and David N. Schwartz, St Martin's Press, New York, 1987, pp. 11-24; and Robert O'Neill, Strategic Studies and Political Scientists: Strategic Studies and Its Critics Revisited, SDSC Working Paper No. 40, Canberra, 29 April 1981.

2 Bull, 'Strategic studies and its critics', p. 11.

3 O'Neill, 'Arms control and the balance of power', in O'Neill and Schwartz, Hedley Bull on Arms Control, p. 55.

4 See Australian Strategic Analysis and Defence Policy Objectives, September 1976, in A History of Australian Strategic Policy Since 1945, ed. Stephan Fruehling, Defence Publishing Service, Canberra, 2009, p. 549. 
narrow definition. For example, there are issues to do with soft power for coercive ends and new challenges such as the strategic implications of climate change. There is also important interaction between military, economic, political and other factors shaping the international strategic environment.

Hedley Bull listed the distinguishing features of what was then the new style of strategic analysis as follows:

- Strategic thinking was no longer exclusively concerned with the efficient conduct of war and the preserve solely of the military.

- Strategic thinking was necessarily abstract and speculative in character because there had not yet been a nuclear war.

- A characteristic of strategic thinking at that time was its sophistication and high technical quality because the intellectual resources now being devoted to strategic studies are without precedent'. This had resulted in a literature of higher technical quality and a discussion of a higher standard of sophistication than had existed before. ${ }^{5}$

These views might seem a little strange from our present-day perspective, but it needs to be remembered that this was during the Cold War, and strategic studies had had a difficult and contentious birth. This is reflected in Hedley Bull's detailed rebuttal of the critics of the work of civilian strategists, including accusations that they leave morality out of account and are indifferent to the moral standing of the causes for which war is undertaken. His response to this was that strategists as a class are neither any less nor any more sensitive to moral considerations than are other intelligent and educated persons in the West. ${ }^{6}$ Additional accusationsand Bull's responses-included:

- Strategists 'take for granted the existence of military force and confine themselves to considering how to exploit it, thereby excluding a whole range of policies such as disarmament or non-violent resistance'. Bull's response to this was that strategists take the fact of military force as the starting point because the capacity for organised violence between states is inherent in the nature of man [sic] and his environment.

- Strategists 'are inclined to make unreal assumptions about international politics ... that simplify and distort political reality and do not allow

5 See Bull, 'Strategic studies and its critics', pp. 11-14.

6 Ibid., pp. 15-24. 
for change'. Bull acknowledged that this was a complaint with a great deal of force because the technical rigour and precision of much strategic analysis had been achieved 'at the cost of losing touch with political variety and change'.

- Civilian strategists 'are pseudo-scientific in their methods; the specialist techniques they employ-such as game theory, systems analysis, simulation and the writing of scenarios-are bogus when used to arrive at strategic decisions and serve to give an air of expertise to positions arbitrarily and subjectively arrived at'. His retort to this was to recognise the limits of rigour and precision and to be on guard against their misuse rather than abandoning rigour and precision in favour of something else. He observed, in his well-known trenchant manner, that the strategist cannot be held responsible for the use that others make of his ideas.

- The strategist 'is detached and aloof, but he has no right to be'. The strategists, 'who have the ear of the powerful, might accomplish great things if they abandon the strategic mode of reasoning for the conscientious, but instead they are collaborators in the system and are speeding up its movement toward catastrophe'. Bull replied that civilian strategists have at least charted some reasoned course where otherwise there might well have been only drift. This has provided some solid intellectual fare that subsequent generations are likely to recognise as a serious attempt to come to grips with the problem. He concluded that it was difficult to escape the conclusion that even though the civilian strategists have sometimes committed errors, 'they have served us well'.

What strikes me in all of this is just how defensive Hedley Bull had to be in justifying the legitimacy of the intellectual role of civilian strategists, particularly in the new field of arms control and the central nuclear balance. Robert O'Neill has told me that in 1968 one had to be on one's guard when writing about strategic studies because the academic culture was unsympathetic - more so in Australia than in the United Kingdom. ${ }^{7}$ Bull's intellectual challenges remind me more of the era immediately after the end of the Cold War than any challenges we might be currently experiencing. As I have recorded elsewhere, with the sudden collapse of the Soviet Union in 1991, SDSC had to adjust dramatically to an altered international strategic environment and to new subjects for strategic

7 R.J. O’Neill, personal communication (email to author), 2 September 2016. 
analysis. ${ }^{8}$ We had entered a new era with Francis Fukuyama's 'end of world history' thesis and the need to retool traditional strategic studies to our region. Those of us who had spent most of our careers focusing on the USSR and the risks of nuclear war between that country and the United States suddenly had to reinvent ourselves. The end of superpower confrontation meant that much more attention could now be paid to the question of improving regional security dialogue and developing a new security architecture. A whole new range of issues surfaced in the regional strategic agenda, including major challenges that changes in the nature of conflict presented to many nations in the development of their armed forces as well as an increased demand for high-level education on strategic and defence policy issues in an era with no clear threats.

As it so happened, Australian strategic thinkers were well prepared for the latter challenge because of pioneering work on concepts for the defence of the Australian continent and how to structure a defence force without an identifiable military threat. SDSC's research on regional security, for example, was expanded to include the effect of population movements, security problems caused by environmental concerns, the relevance of the Revolution in Military Affairs to regional countries, regional defence decision-making, the US-Japan relationship, Indonesian defence developments, China's foreign and defence policies, and developments in North Korea as well as terrorism and transnational crime. ${ }^{?}$

SDSC has adjusted quite well to the new security challenges in the post-Cold War era and established a reputation for being the leading academic authority in Australia on Asia-Pacific regional security issues. So the question facing us now is more what to do with our rapid growth and success in the last decade or so. SDSC now has 27 members of staff compared with only five in the mid-1990s, when it had almost ceased to exist, not least because of reduced Australian National University (ANU) priorities for our research on defence-related issues. Now, the challenge facing us is an ever-expanding strategic studies agenda and teaching load and determining what direction and priorities should drive us. We must not allow strategic studies to become paralysed by the endless range and scope of potential issues to study that face us.

8 Paul Dibb, 'SDSC in the nineties: A difficult transition', in A National Asset: Essays Commemorating the 40th Anniversary of the Strategic and Defence Studies Centre, ed. Meredith Thatcher and Desmond Ball, Strategic \& Defence Studies Centre, The Australian National University, Canberra, 2006, pp. 84-7.

9 Ibid., p. 86. 


\section{Whither strategic studies?}

The first question to address is whether strategic studies should be separated from international relations and such disciplines as international political economy. Hedley Bull did not believe that it was desirable to separate strategic studies from the wider study of international relations, although he said it could be argued that it compares very favourably with some other branches of political science, both in its moral and social relevance and as an intellectual discipline. ${ }^{10} \mathrm{He}$ acknowledged the emergence of strategic studies as an appropriate subject for inclusion in university curricula. And he observed the fact that strategic expertise had come 'to have a political function as an ideology is inevitable and, I believe, by no means wholly regrettable'. ${ }^{11}$ This was quite a remarkable and bold observation to make at that time. I have experienced remarks in the past that SDSC would be more appropriately located not in a university but in a defence college because of moral and ideological concerns. However, we certainly have not known the hostility that SDSC faced during the Vietnam War and the sort of baseless moral suspicions that Bob O'Neill experienced. ${ }^{12}$ Nevertheless, my view is that the nexus between strategic studies and international relations has drifted further apart since Bull's time as international relations has become more theoretical in its analysis. Strategic studies is now firmly established as a separate academic discipline, less preoccupied with theory and more practical in its application. But, needless to say, sound strategic analysis should be founded on an intellectually rigorous conceptual base. Moreover, we should continue to have a close relationship with international relations departments on international political issues. In the end, there will always be inevitable tension between ideas of strategy and ideas of security more generally and how Australia might respond to them, as I will argue below.

Second, proposals have been raised recently for SDSC to be moved out of the Coral Bell School of Asia Pacific Affairs to become part of the Crawford School of Public Policy at ANU. In my view, that proposal is to be strongly rejected. It is crucial that we stay in close contact with particular parts of the College of Asia and the Pacific because of their knowledge of key countries in Australia's strategic environment—especially

10 Bull, 'Strategic studies and its critics', p. 14.

11 Ibid., p. 21.

12 O'Neill, Strategic Studies and Political Scientists, p. 5. 
South-East Asia (particularly Indonesia), the South Pacific (particularly Papua New Guinea) and North-East Asia (especially China and Japan). These are countries that define Australia's strategic neighbourhood and where Australia has particular responsibilities and concerns. Little of this expertise exists in the Crawford School of Public Policy.

Third, unlike 20 years ago when I headed the Centre, SDSC faces an array of competing organisations that have specialised in particular areas. The Australian Strategic Policy Institute (founded in 2001) focuses heavily on defence policy from a practical perspective, offering alternative policy advice to the government from that of the defence organisation. Then there is the Lowy Institute (founded in 2003) with its wide international political mandate, the National Security College (founded in 2010) with its focus on national security issues and the education of public servants, and the US Studies Centre (founded in 2006) with its concentration on the United States and Australia's relations with it. There are other organisations that cater for a broader audience, such as the Kokoda Foundation (now renamed the Institute for Regional Security), as well as a growing number of university departments studying and teaching international strategic subjects.

All this has encouraged SDSC to focus more on what should be its primary educational purpose, which is to teach strategic studies and defence policy at the undergraduate and postgraduate levels. As a result, there has been a huge expansion in the Centre's teaching responsibilities with a master's program at ANU numbering about 70 students and an undergraduate program currently involving some 280 enrolments, as well as a highly successful master's program for the Command and Staff College course at the Australian Defence College. The size and diversity of this teaching program is without parallel anywhere else in Australia. It gives SDSC the opportunity to train the next generation of strategic thinkers nationwide, and we need to pay more attention to this goal and developing strong alumni linkages.

At the same time, the Centre needs to think carefully about the quickly growing number of new national security issues that are being raised for academic research and teaching. For example, what should be the contribution of strategic studies to such topics as terrorism, cyber warfare and climate change? Arguably, all three of these are of concern to a nation's national security. The current wave of extremist Islamic terrorism is an enormous threat to the very fabric of Western civilisation. Understanding 
the origins of terrorism, why it has been spawned by a particular extremist interpretation of the Islamic faith and how to counteract it are extremely challenging questions for governments. SDSC currently has no expertise in this area, although in the past it had one person who was a long-established terrorism expert. However, studying terrorism demands a different set of intellectual methodologies from traditional strategic studies of powerbased relations between nation states. It requires a deep knowledge of Islam, its Middle Eastern origins and - not least-the backgrounds and actions of individual terrorists. My view is that this is a highly specialised area and is more appropriately located in such institutions as national security colleges and university departments specialising in terrorism.

Similarly, the threat from cyber attacks and understanding both defensive and offensive retaliatory measures demands very specialised technical expertise that few academics yet possess. Moreover, the demand for this specialised knowledge is high, not only from governments but also from the private sector, given their vulnerabilities to penetration from foreign governments and individual hackers. Again, my view is that the intellectual and technical skills demanded are very different from conventional academic training, at least in the social sciences, so we are better off leaving it to such organisations as the Australian Strategic Policy Institute, which has established a specialised International Cyber Policy Centre that produces an annual report called Cyber Maturity in the AsiaPacific Region, which has become the definitive work on this topic. ${ }^{13}$ This publication is the result of 12 months of research and analysis delving into the cyber maturity of 20 countries in our region. I see no point in SDSC seeking to allocate scarce academic resources to this space.

Finally, there is the vexed question of climate change. There can be no doubt that this is a legitimate area for academic research, including in the broader strategic studies arena. The defence organisations of both the United States and the United Kingdom have identified it as an area of strategic concern, although the Australian 2016 Defence White Paper makes no specific reference to the challenges of climate change (whereas it does address the threats from terrorism and cyber attacks). ${ }^{14}$ The security threat from climate change gets only a passing reference in the White

13 Tobias Feakin, Jessica Woodall and Liam Nevill, Cyber Maturity in the Asia-Pacific Region 2015, International Cyber Policy Centre, Australian Strategic Policy Institute, October 2015.

14 Australian Government, 2016 Defence White Paper, Department of Defence, Commonwealth of Australia, Canberra, 2016, pp. 46-8, 51-2, www.defence.gov.au/WhitePaper/Docs/2016-DefenceWhite-Paper.pdf (retrieved 16 January 2018). 
Paper, being identified as 'a major challenge for countries in Australia's immediate region'. ${ }^{15}$ This statement is made in the context that increased sea-level rises and the frequency and intensity of extreme weather events 'will exacerbate the challenges of population growth and environmental degradation, and will contribute to food shortages and undermine economic development'. ${ }^{16}$

However, the Defence White Paper offers little practical guidance about the implications of this for the Australian Defence Force, other than helping Pacific island countries build their resilience to natural disasters. ${ }^{17}$ Humanitarian assistance and disaster relief missions are obviously an important ADF contribution to the security of the South Pacific. But the White Paper does not address the implications of severe climate-induced inundation of low-lying, vulnerable South Pacific countries. It is a major deficiency in the Defence White Paper that the strategic implications of such events are not addressed. There is important research work here for SDSC to do in cooperation with the world-class academic expertise on the South Pacific resident in The Australian National University's College of Asia and the Pacific.

\section{Priorities for strategic studies in the 2020s}

Longer-term priorities for academic strategic studies research will depend on events as they unfold, not least because of unpredictable 'black swan' shocks to the system such as the collapse of the Soviet Union or the election of Donald Trump as President of the United States. But some potentially threatening new trends can be identified now. In my view, we are entering an exceedingly dangerous era for which we are ill-prepared intellectually. My basic thesis is that forces of anti-Western nationalism are on the rise in Russia and China at the same time as Western democracies are being undermined by extreme Islamic terrorism assaults and the growth of xenophobic domestic attitudes to the outside world, as we have witnessed in the US presidential election in November 2016. We do not have a term yet for this new instability, but it should focus around unpredictable new nationalisms. Of course, nationalism has raised its ugly head before in recent history. As Barbara Tuchman observes in her book

15 Ibid., pp. 55-6.

16 Ibid.

17 Ibid., p. 74. 
The Proud Tower, the last time events of this sort coincided in the same way was between 1890 and $1914 .{ }^{18}$ That period was a pivotal moment in world history when widespread, violent anarchist terrorism and the helplessness of society to defend itself occurred at precisely the same time as the geopolitical challenge to the established power of Great Britain from the rising military power of Germany. The nations of the West were self-satisfied and setting themselves up, all unwittingly, for the catastrophe to come in World War I. This was a time of the most accelerated rate of change in human experience as industrial and scientific revolutions were transforming the world and undermining traditional employment certainties. The parallels with today are unsettling. I am not predicting here that history will repeat itself, but we are entering a dangerous era because of the following coincidence of events:

- Russia and China, both authoritarian powers, are challenging the Western liberal order through the use of military force and coercion. They are aligned in their hostility towards the United States and its democratic allies and are now seeking to alter international borders and extend their territories-for example, in the South China Sea and Ukraine. Unlike Russia, China is not yet using military force to assert its territorial claims, but it is using such harsh coercion and militarisation of its territorial claims that it is causing serious alarm in its neighbourhood.

- All this is occurring just as Western electorates are experiencing a yawning gap between governments and governed. Domestic politics in the West are in disarray as a result of the impact of globalisation, illegal immigrants and the control of borders. There is deep-seated anger in the United States and United Kingdom as well as other European countries about the loss of jobs and falling living standards. Governments are becoming increasingly challenged by the effects of globalisation on their domestic politics. A new political divide is occurring in Western democracies in which populous, xenophobic and anti-globalist politicians are on the rise and promising to put up walls to keep out the world. We have witnessed these dramatic forces at work most dramatically in recent years in both the United States and Britain.

18 Barbara W. Tuchman, The Proud Tower: A Portrait of the World Before the War, 1890-1914, Hamish Hamilton, London, 1966. 
- At the same time, Western democracies are facing an unprecedented assault by Islamic fundamentalist terrorists. This has now become so intense and on such a scale that, for example, fears have been expressed by the head of France's domestic intelligence organisation of civil war erupting. The very basis of Western civilisation is being deliberately undermined.

The above suggests some new research agendas for strategic studies, including the need for better analysis of the military capabilities of China and their implications for Australia. This means having a dedicated academic position to research independently the details of China's strategic policies and its military strengths and weaknesses. Understanding China is now a crucial strategic question for Australia.

Nuclear deterrence is re-emerging as a serious topic for research. Nuclear capabilities and their potential use is an area where the end of the Cold War and the disappearance of the threat of global nuclear war has led to complacency about these hugely destructive weapons. This is especially of concern in our own region, where there is a strong latent potential in several countries to acquire nuclear weapons with comparatively little warning.

The economic geography of globalisation and its implications for social and political stability in Western countries now warrants the recruitment of an economist with geographical skills and knowledge about how economic and technical globalisation affects countries-and specific regions within countries_-in different ways strategically.

We will need access to research on the implications of extreme Islamic fundamentalist terrorism for stability in key Western countries that are allies of the United States. This does not mean that strategic studies should now become expert on the details of terrorist attacks. Rather, we need deep insights into the implications of terrorism for the fundamental social cohesion of nation states in the West.

The implications of President Trump in Washington for security in the Asia-Pacific region demand a rethink of Australia's security outlook and the fundamental basis of our alliance with the United States so that we understand the policy choices now facing us. The most radical change to our national security policy settings since World War II has occurred with the election of Trump as President of the United States. This should be an important task for The Australian National University's Coral Bell 
School of Asia Pacific Affairs. It will involve bringing together strategic studies, international relations and area expertise on both our region and the United States in fundamental new ways.

With regard to defence policy, SDSC needs to return to its core business and rebuild its expertise in this traditional area of its research. We need to reappraise regularly the conclusions set forth in the 2016 Defence White Paper to challenge their continuing validity. For example, some groundbreaking research needs to be undertaken about the implications for Australia if the comfortable timeframes of the 2016 Defence White Paper are wrong: such as the assertion that 'there is no more than a remote possibility of a military attack on Australian territory by another country in the period to $2035^{\prime} .{ }^{19}$ What I have in mind here is that we need to be prepared for a quicker deterioration in our fundamental strategic circumstances if China's military ambitions result in armed conflict with the United States and Japan. This would have important implications for the expansion base of the ADF and for its mobilisation.

Our role in education could be taken a bit higher up the scales of seniority and responsibility by hosting discussion groups, small conferences and one-on-one sessions involving senior public servants and military officers, diplomats and rising young politicians. ${ }^{20}$ These need not be very timeconsuming but would be arranged to be a good fit between student and teacher, and could be coordinated with other relevant parts of ANU, other universities and perhaps with key regional strategic studies centres. The major political parties and relevant parliamentary committees might welcome more such interaction with the Strategic \& Defence Studies Centre.

Finally, there is the question of where policy-relevant work should figure in the research priorities of strategic studies in the second decade of the 21 st century. There is growing recognition of the practical value of such research in Australian universities. However, as there was in Hedley Bull's day, there is lively debate today as to whether it is appropriate for academics in strategic studies to give consideration to the implications of their scholarly work for the policies of governments. At a time when so many of the challenges I have mentioned are arising, this is said to be a very important part of The Australian National University's stated

19 Australian Government, 2016 Defence White Paper, p. 40.

20 I am indebted to Professor R.J. O'Neill for the suggestions in this paragraph. 
strategic plan and mission. However, it still seems to be the case that some in academia consider it is not appropriate to suggest what are the implications of their scholarly work for Australian policy. While respecting their views, and without sacrificing academic independence, I consider it behoves us to inform the wider Australian community appropriately about such serious national security policy questions. 
This text is taken from New Directions in Strategic Thinking 2.0:

ANU Strategic \& Defence Studies Centre's Golden Anniversary

Conference Proceedings, edited by Dr Russell W. Glenn, published 2018 by ANU Press, The Australian National University, Canberra, Australia. 